\title{
An entrepreneurial Culture Led by Creativity and Innovation: Challenges and Competencies for Sri Lanka as a Middle Income Country
}

\author{
Dr. Tissa Ravinda Perera \\ Senior Lecturer \\ Department of Management and Organization Studies \\ Faculty of Management \& Finance \\ University of Colombo \\ Colombo 07 \\ Sri Lanka
}

\begin{abstract}
An open economic policy was introduced by Sri Lanka in 1977, before many other countries in Asia to align her economy to world economic trends. Before 1977 Sri Lanka mainly followed an inward looking economic policy whereas from 1977 onwards Sri Lanka adopted an outward looking or open economic policy. After 1977 with the introduction of the open economic policy, indigenous businesses had to compete with foreign products, processes, technology, innovations and businesses. Hence, doing businesses in this context was very complex as well as more dynamic than in the past. In the year 1977 Sri Lanka converted from public entrepreneurship to private entrepreneurship. Therefore, the country triedto develop through private entrepreneurship from 1977; not only because it the engine of growth, but also to align the country's development process to world inclinations. The year 2010 was a milestone in Sri Lankan history to achieve the developmental goals when Foxbuisness rated Sri Lanka as the best performing global economy. However, Sri Lanka missed her chances of achieving development with the political and social chaos, consequent the regime change in 2015. To support the fundamental assumption of engine of growth, Sri Lanka must develop an entrepreneurial culture through creativity and innovation. In this endeavor, creativity and innovation will definitely play a pivotal role to achieve the desired level of development with competitive advantage. This type of a development will be an example to the rest of the world and Sri Lanka will be held as a "Model State" for others to follow in today's context as it was done in the past in Singapore. It is important to get the support of Universities, other educational institutions and organizations which support businesses in the country to develop an entrepreneurial culture in the country and the Government's support with a national level policy for an entrepreneurial culture. All of these will give sustainability to entrepreneurial culture movement in the country. At the same time, the development of the entrepreneurial culture must be associated with creativity and innovation to gain competitive advantage over the development strategies of other countries and other emerging countries like Sri Lanka. An entrepreneurial culture will help minorities, women and under privileged societies to empower themselves. At the same time it will help to confront and manage youth unrest which has created anarchy in the country from time to time.
\end{abstract}

Keywords: Economy, industry, creativity, innovation, entrepreneurship, entrepreneurial culture

\section{Prelude}

Sri Lanka introduced the open economic policy in the year 1977 before many other countries in Asia to align her economy to world economic trends and to earn a higher economic growth whilst using innovations and new product developments along with development of new services. Before 1977 Sri Lanka mainly followed an inward looking economic policy whereas from 1977 onwards Sri Lanka adopted an outward looking or open economic policy. The inward looking economic policy promoted many indigenous businesses since the Government promoted local businesses by giving many incentives and subsidies to them. However, after 1977 with the introduction of the open economic policy, indigenous businesses had to compete with foreign products, processes, technology, services, innovations and businesses. Hence, doing businesses in this context was very complex as well as more dynamic than in the past. Therefore, currently Sri Lanka is in such a situation of complexity and a dynamic environment in all that she does. In the year 1977 the private sector was made the engine of growth and it was given the authority and precedence to drive the country's economic growth. This was a transfer from public entrepreneurship to private entrepreneurship in Sri Lanka to develop the country. Therefore, the country must try to see new boulevards to develop the country through private entrepreneurship not only because it is the engine of growth, but also to align the country's development process to world inclinations. 
As a country Sri Lanka must try to promote entrepreneurship whilst developing an entrepreneurial culture along with promoting creativity and innovations in businesses, thus developing Sri Lanka as a great developed nation physically and spiritually. In this endeavor, creativity and innovation will definitely play a vital role to achieve the development goals of the country with a competitive advantage over other countries. This development will be an example for the rest of the world and Sri Lanka will be held up a "model state" for others to follow in today's context as done in the past for Singapore.

\section{Sri Lankan Economy in the Bygone Years}

Sri Lanka had an agricultural economy at the time of achieving her independence in 1948 from the British. Income from tea, rubber and coconut highly contributed to the national income. More than $50 \%$ of the seven million people in the country were employed in the agricultural sector. In 1948 more than $40 \%$ of the national income came from the agricultural sector. All the other sectors such as banks, insurance and transportation were depending on the agricultural sector. The economy was opened for free trade and $70 \%$ of the gross domestic product came from imports and exports. Economic growth rate of the country was about 4.2 during the first five decades after independence. In 1948 per capita income was $\$ 120$ (at current prices Rs. 397) and it was \$ 3,835 (at current prices Rs. 542,669) in 2016.The inflation rate was about 7\% during this time. Economic growth rate from 1950 to 1960 was 3.1 and it was 5.2 from 2001 to 2010.After the successful end of the internal conflict, in 2010, Sri Lanka was able to attain a higher level of economic growth 0f9.4 in 2011 and 9.1 in 2012 respectively. The unemployment rate was $11.9 \%$ in 1948 and it was $24 \%$ in 1973. Sri Lanka became a democratic country after independence in 1948. Masses of the country had changed Governments many times for the purpose of achieving development through which achieving a higher level quality of life was expected. All Governments have faced the same issues in Sri Lanka with respect to development matters. They were puzzled about how to develop the nation and achieve economic growth. Sri Lanka faced many economic policy changes, world market behaviors, changes in product and service prices, climatic changes and internal conflicts. All Governments tried to improve the quality of infrastructure in the country after independence with their capacity. Before 1977 Sri Lanka mainly followed an inward looking economic policy whereas from 1977 onwards Sri Lanka followed an outward looking or open economic policy. Sri Lanka was rated as the best performing global market in 2010 by Fox buisness. In 2010 Sri Lanka should have started her journey to achieve developmental goals. However, Sri Lanka missed her opportunity to achieve the desired level of development with the political and social anarchy consequent to regime power change in 2015. The following Table 01: Macro-Economic Performance of Sri Lanka (1978-2012) shows it in a nutshell.

Table 01: Macro Economic Performance of Sri Lanka (1973-2012)

\begin{tabular}{|c|c|c|c|c|}
\hline Indicator & 1978 & 1998 & 2002 & 2014 \\
\hline National Income (US\$ MN) & 2733 & 15761 & 16532 & 74944 \\
\hline GNP Growth rate (Rs.) & 8.2 & 4.6 & 4.0 & 7.5 \\
\hline GDP Per capita (US\$) & US\$ 176 & US\$ 879 & US\$ 872 & US\$ 3625 \\
\hline GNP Per capita (US\$) & US\$ 172 & US\$ 865 & US\$ 858 & US\$ 3536 \\
\hline \multicolumn{5}{|l|}{ GDP sectorial composition } \\
\hline Agriculture & 32.3 & 21 & 20 & 10.1 \\
\hline Industry & 18.4 & 27.5 & 26 & 32.4 \\
\hline Service & 44.4 & 51.4 & 53.6 & 57.6 \\
\hline Population growth rate & 1.8 & 1.1 & 1.4 & 0.9 \\
\hline \multicolumn{5}{|l|}{$\begin{array}{l}\text { Other Economic Indicators } \\
\text { (As \% of GDP) }\end{array}$} \\
\hline Unemployment rate & $` 14.7(1978 / 79)$ & 9.2 & 9.1 & 4.3 \\
\hline Investment & $19.9 \%$ & 22.2 & 21.3 & 29.7 \\
\hline National savings & $15.3 \%$ & 19.1 & 19.7 & 27.0 \\
\hline \multicolumn{5}{|l|}{ Socio Economic Indicators } \\
\hline Birth rate & 28.5 & 18.2 & 19.1 & 16.9 \\
\hline Death rate & 6.6 & 6.2 & 5.8 & 6.2 \\
\hline Literacy rate & 86.2 & 91.8 & 90.7 & 92.5 \\
\hline HDI & $0.653(1980)$ & $0.706(1990)$ & $0.747(2000)$ & 0.750 \\
\hline Life expectancy & 69 & - & 74 & 74 \\
\hline Poverty ratio & - & $28.8(1995 / 96)$ & 22.7 & 6.7 \\
\hline Gini coefficient & 0.43 & $0.46(2003 / 04)$ & $0.46(2003 / 04)$ & 0.48 \\
\hline Exchange rate \$/Rs. & 15.15 & 94.0 & 98.00 & 130.56 \\
\hline Consumer price index & 227.8 & 2284.9 & 3176 & 5022 \\
\hline
\end{tabular}

Source: Central Bank of Sri Lanka 
The Sri Lankan economy was agricultural based since her independence. This was the trend up to the 1950s.However, it changed in the 1960s and the contribution from the services sector took first place from 1960s onwards. There is a peculiarity in the Sri Lankan economy in that she has a higher service sector than in an industrial sector which is somewhat peculiar when compared to other developing nations and countries which had developed before. Table 02: Structural Changes in GDP of Sri Lanka from 1950 to 1960 clearly demonstrating this scenario.

Table 02: Structural Changes in GDP of Sri Lanka from 1950 to 2010

\begin{tabular}{|c|c|c|c|}
\hline Year & Agriculture & Industry & Services \\
\hline 1950 & 46.3 & 19.6 & 36.9 \\
\hline 1960 & 37.8 & 16.8 & 45.4 \\
\hline 1970 & 28.3 & 23.8 & 47.9 \\
\hline 1980 & 27.6 & 29.6 & 42.8 \\
\hline 1990 & 26.3 & 26.0 & 47.7 \\
\hline 2000 & 19.9 & 27.3 & 52.8 \\
\hline 2010 & 12.8 & 29.4 & 57.8 \\
\hline
\end{tabular}

Source: Annual Reports (Central Bank of Sri Lanka)

\section{Present Economic Status Of Sri Lanka}

After the effective end of the internal conflict in 2010 in Sri Lanka, the environment was peaceful for business and investments throughout the country amides simple political issues prevailing in the country. Sri Lanka has come to a middle income country during last a few years and the Government has planned to transform Sri Lanka into a strategically important economic center by developing five strategic hubs; a knowledge hub, a commercial hub, a naval and maritime hub, an aviation hub, and an energy hub, taking the advantage of Sri Lanka's strategic location and resources. In changing these development goals Governments are trying to align their strategies accordingly. All economic indicators has improved in the country during last a few years with a $57 \%$ contribution coming from the service sector which remains the largest contributor to the national economy even today. The strong economic performances and initiatives taken in Sri Lanka have hoisted the country's per capita income enabling her to be a middle income country within a short period of time after the internal conflict. Table 03: Recent economic indicators in Sri Lanka summarize recent economic development and her indices related to the economy.

Table 03: Recent Economic Indicators in Sri Lanka

\begin{tabular}{|l|l|l|l|}
\hline \multicolumn{1}{|c|}{ Indicators } & \multicolumn{1}{|c|}{$\mathbf{2 0 1 4}$} & \multicolumn{1}{c|}{$\mathbf{2 0 1 5}$} & \multicolumn{1}{|c|}{$\mathbf{2 0 1 6}$} \\
\hline GDP Growth Rate (\%) & 5.0 & 4.8 & 4.4 \\
\hline Per Capita Income (at current prices \$) & 3821 & 3844 & 3835 \\
\hline State of GDP at constant (2010) market Prices & & & \\
Agriculture & 8.0 & 8.2 & 7.5 \\
Industry & 28.3 & 27.3 & 27.1 \\
Services & 56.9 & 57.3 & 57 \\
\hline Labor Force Participation Rate & 53.2 & 53.8 & 53.8 \\
\hline Labor Force Participation by Gender & & & \\
Male & 74.6 & 74.7 & 75.1 \\
Female & 34.6 & 35.9 & 35.9 \\
\hline Labor Force Participation by Rural, Urban & & & \\
Sectors & 48.7 & 48.6 & 49.8 \\
Urban & 54.1 & 54.8 & 54.6 \\
Rural & 4.3 & & \\
\hline Unemployment rate & & & 4.7 \\
\hline Unemployment Rate by Gender & 3.1 & 3.0 & 2.9 \\
Male & 6.5 & 7.6 & 7.0 \\
\hline Female & & \\
\hline
\end{tabular}

Source: Department of Census and Statistics and Various Central Bank Reports

According to table 04 and table 05 it is clear how Sri Lanka became a middle income country along with her economic growth rate with time. 
Table 04: Time Taken to Double GNP Per Capita

\begin{tabular}{|l|l|l|l|l|l|}
\hline Year & Per Capita & $\begin{array}{c}\text { Time Taken } \\
\text { (Years) }\end{array}$ & Decade/Year & GDP Growth Rate & Years required \\
\hline $\mathbf{1 9 6 0}$ & 142 & 0 & $\mathbf{1 9 5 1 - 6 0}$ & 3.1 & 23 \\
\hline $\mathbf{1 9 7 5}$ & 281 & 15 & $\mathbf{1 9 6 1 - 7 0}$ & 4.7 & 15 \\
\hline $\mathbf{1 9 9 1}$ & 547 & 16 & $\mathbf{1 9 7 1 - 8 0}$ & 5.9 & 12 \\
\hline $\mathbf{2 0 0 4}$ & 1062 & 13 & $\mathbf{1 9 8 1 - 9 0}$ & 4.3 & 17 \\
\hline $\mathbf{2 0 0 8}$ & 2014 & 4 & $\mathbf{1 9 9 1 - 2 0 0 0}$ & 5.2 & 14 \\
\hline $\mathbf{2 0 1 6}$ & 4000 & 7 & $\mathbf{2 0 0 1 - 2 0 1 0}$ & 5.2 & 14 \\
\hline
\end{tabular}

Source: Annual reports, Central Bank of Sri Lanka

Currently, Sri Lanka has come to the level of a middle income country and she has a long way go to achieve the required level of development to crown her as a developed country in the world. China, India, Indonesia and Vietnam are some of the countries who are competitors to Sri Lanka in regard to the development. In other words, Sri Lanka must look at the experiences in these countries and their strategies in achieving their development. Table 06: GDP World Comparison shows the growth rates of counties and regions in time series for understanding this scenario.

Table 06: GDP World Comparison

\begin{tabular}{|l|c|c|c|c|c|c|}
\hline \multicolumn{1}{|c|}{ Reigion/ Country } & $\begin{array}{c}\text { Average } \\
\mathbf{1 9 9 8 - 2 0 0 7}\end{array}$ & $\mathbf{2 0 1 1}$ & $\mathbf{2 0 1 2}$ & $\mathbf{2 0 1 3}$ & $\mathbf{2 0 1 4}$ & $\mathbf{2 0 1 5}$ \\
\hline World & 4.2 & 4.2 & 3.5 & 3.3 & 3.4 & 3.1 \\
\hline Advanced Economies & 2.8 & 1.7 & 1.2 & 1.2 & 1.8 & 1.9 \\
USA & 3.0 & 1.6 & 2.2 & 1.5 & 2.4 & 2.4 \\
Japan & 1.0 & -0.5 & 1.7 & 1.4 & 0.0 & 0.5 \\
Germany & 1.7 & 3.7 & 0.6 & 0.4 & 1.6 & 1.5 \\
\hline Emeraging and Developing Europe & 4.2 & 5.4 & 1.2 & 2.8 & 2.8 & 3.5 \\
\hline Emerging and Developing Economies & 5.8 & 6.3 & 5.3 & 4.9 & 4.6 & 4.0 \\
\hline Emerging Developing Asia & 7.6 & 7.8 & 6.9 & 6.9 & 6.8 & 6.6 \\
China & 9.9 & 9.5 & 7.7 & 7.7 & 7.3 & 6.9 \\
Indonesia & 2.7 & 6.2 & 6.0 & 5.6 & 5.0 & 4.8 \\
India & 7.1 & 6.6 & 5.6 & 6.6 & 7.2 & 7.3 \\
\hline Sri Lanka & 5.0 & 8.4 & 9.1 & 3.4 & 4.9 & 4.8 \\
\hline Latin American and the Caribbean & 3.1 & 4.9 & 3.2 & 3.0 & 1.3 & -0.1 \\
\hline Middle East, North Africa, Afghanistan and & 5.3 & 4.5 & 5.0 & 2.3 & 2.8 & 2.5 \\
Pakistan & & & & & & \\
\hline Sub Sharan Africa & 5.3 & 5.0 & 4.3 & 5.2 & 5.1 & 3.4 \\
\hline
\end{tabular}

Sources: World Economic Outlook (April 2016, IMF), Depramtent of Census and Statisitics, Central Bank of Sri Lanka

Unemployment has been an issue in Sri Lanka for long and many Governments have tried to solve this issue by taking many strategic initiatives. Sri Lanka has faced several internal conflicts due to economic problems, unemployment and sporadic youth unrest. According to the view of sociologists, anthropologists and intellectuals the internal conflicts faced by Sri Lanka for 30 years and the 1971 and 1989 insurrections were manifestations of such issues. Therefore, Sri Lanka needs a rigorous and a sustainable solution for unemployment for her to achieve the set development goals. Table 07: Unemployment Rates by District shows the districts which have the lowest percentages of unemployment and the highest percentages of unemployment in Sri Lanka district wise.

Table 07: Unemployment Rates by District

\begin{tabular}{|l|l|l|l|l|l|l|l|l|}
\hline District & Polonnaruwa & Colombo & Kalutara & Matale & Mannar & Jaffna & Ampara & Matara \\
\hline $\begin{array}{l}\text { Highest } \\
(\%)\end{array}$ & & & & 7.6 & 7.1 & 7.0 & 6.6 & 6.5 \\
\hline Lowest (\%) & 2.5 & 2.9 & 3.0 & & & & & \\
\hline
\end{tabular}

Source: Department of Census and Statistics of Sri Lanka 
Table 08 shows the unemployment rate by selected age groups and gender from 2011 to 2016. Accordingly the table clearly indicates that the age group from 15 to 24 there has a high unemployment rate and the next group from 25 to 29 is second to it. Therefore, it indicates that the active and young community in the country has an issue with regards to their employment. However, the individuals who are in the age group from 15 to 24 consists of schools goers as well. This has an indication for policy makers to look into and analyze deeply about the country's development goals as well as to redefine such goals to align with the modern environment. The country must think about preventing a possible chaos that she had for 30 years, in 1971 and 1989 by providing people with economic empowerment. It is also evident that the female unemployment rate is higher than male unemployment rate. Therefore, the country must take some action to create more opportunities for them to align with the global trend of ensuring the equal rights of women. At present, the enigma is "How to do it?"

Table 08: Unemployment Rate by Selected Age Groups and Gender (2011-2016)

\begin{tabular}{|l|l|l|l|l|l|l|l|l|l|}
\hline \multirow{2}{*}{$\begin{array}{l}\text { Age Group } \\
\text { Years) }\end{array}$} & \multicolumn{4}{|c|}{$\mathbf{2 0 1 1}$} & \multicolumn{3}{c|}{$\mathbf{2 0 1 2}$} & \multicolumn{3}{c|}{$\mathbf{2 0 1 3}$} \\
\cline { 2 - 11 } & Total & Male & Female & Total & Male & Female & Total & Male & Female \\
\hline Total & 4.2 & 2.7 & 7.1 & 4.7 & 3.0 & 7.6 & 4.4 & 2.9 & 7.0 \\
\hline $15-24$ & 17.2 & 12.8 & 25.0 & 20.8 & 16.6 & 27.4 & 21.6 & 17.1 & 29.2 \\
\hline $25-29$ & 7.7 & 4.1 & 14.7 & 9.4 & 4.4 & 17.5 & 9.2 & 5.1 & 15.9 \\
\hline $30-39$ & 2.8 & 1.5 & 5.3 & 3.1 & 1.6 & 5.7 & 2.4 & 0.9 & 5.1 \\
\hline Over 40 & 0.7 & 0.4 & 1.3 & 1.0 & 0.6 & 1.8 & 0.8 & 0.5 & 1.3 \\
\hline $\begin{array}{l}\text { Age Group } \\
\text { (Years) }\end{array}$ & \multicolumn{3}{|c|}{$\mathbf{2 0 1 4}$} & \multicolumn{3}{|c|}{$\mathbf{2 0 1 5}$} & \multicolumn{4}{c|}{$\mathbf{2 0 1 6}$} \\
\cline { 2 - 11 }$y$ & Total & Male & Female & Total & Male & Female & Total & Male & Female \\
\hline Total & 4.3 & 3.1 & 6.5 & 4.7 & 3.0 & 7.6 & 4.4 & 2.9 & 7.0 \\
\hline $15-24$ & 20.3 & 16.1 & 27.5 & 20.8 & 16.6 & 27.4 & 21.6 & 17.1 & 29.2 \\
\hline $25-29$ & 8.2 & 5.8 & 12.5 & 9.4 & 4.4 & 17.5 & 9.2 & 5.1 & 15.9 \\
\hline $30-39$ & 2.7 & 1.5 & 5.0 & 3.1 & 1.6 & 5.7 & 2.4 & 0.9 & 5.1 \\
\hline Over 40 & 0.9 & 0.7 & 1.3 & 1.0 & 0.6 & 1.8 & 0.8 & 0.5 & 1.3 \\
\hline
\end{tabular}

Source: Depratment of Census and Statistics`of Sri Lanka

It is evident that in Sri Lanka, there is a high unemployment rate amongst the educated than the uneducated in general. At the same time the female educated have higher unemployment than the male educated too. Therefore, the country needs to understand a correction course to it as well to prevent the issues faced in the past and to face the future strongly. Thus, what mustSri Lanka do as a country now?

Table 09: Unemployment Rate by Level of Education and Gender (2011-2016)

\begin{tabular}{|l|l|c|c|c|c|c|c|}
\hline \multicolumn{2}{|c|}{ Level of Education } & $\mathbf{2 0 1 1}$ & $\mathbf{2 0 1 2}$ & $\mathbf{2 0 1 3}$ & $\mathbf{2 0 1 4}$ & $\mathbf{2 0 1 5}$ & $\mathbf{2 0 1 6}$ \\
\hline Sri Lanka & & $\mathbf{4 . 2}$ & $\mathbf{4 . 0}$ & $\mathbf{4 . 4}$ & $\mathbf{4 . 3}$ & $\mathbf{4 . 7}$ & $\mathbf{4 . 4}$ \\
\hline Male & 2.7 & 2.8 & 3.2 & 3.1 & 3.0 & 2.9 \\
\hline Female & 7.1 & 6.3 & 6.6 & 6.5 & 7.6 & 7.0 \\
\hline \multirow{5}{*}{ Grade 5 \& Below } & Total & $\mathbf{0 . 7}$ & $\mathbf{0 . 6}$ & $\mathbf{1 . 0}$ & $\mathbf{0 . 9}$ & $\mathbf{0 . 7}$ & $\mathbf{0 . 8}$ \\
\cline { 3 - 8 } & Male & 0.3 & 0.3 & 0.8 & 0.6 & 0.3 & 0.3 \\
\cline { 2 - 8 } & Female & 1.3 & 1.0 & 1.2 & 1.3 & 1.5 & 1.6 \\
\hline \multirow{3}{*}{ Grade 10 \& Below } & Total & $\mathbf{3 . 4}$ & $\mathbf{3 . 2}$ & $\mathbf{3 . 4}$ & $\mathbf{3 . 4}$ & $\mathbf{3 . 4}$ & $\mathbf{3 . 3}$ \\
\cline { 2 - 8 } & Male & 2.6 & 2.6 & 2.7 & 2.9 & 2.6 & 2.7 \\
\cline { 2 - 8 } & Female & 5.3 & 4.7 & 5.0 & 4.6 & 5.4 & 4.6 \\
\hline \multirow{3}{*}{ G.C.E. (O/L) } & Total & $\mathbf{5 . 3}$ & $\mathbf{6 . 0}$ & $\mathbf{6 . 0}$ & $\mathbf{5 . 9}$ & $\mathbf{6 . 4}$ & $\mathbf{5 . 8}$ \\
\cline { 2 - 8 } & Male & 3.4 & 4.6 & 4.7 & 4.4 & 5.1 & 4.1 \\
\cline { 2 - 8 } & Female & 9.1 & 8.9 & 8.5 & 8.9 & 9.0 & 9.1 \\
\hline \multirow{3}{*}{ G.C.E. (A/L) \& Above } & Total & $\mathbf{9 . 1}$ & $\mathbf{7 . 6}$ & $\mathbf{8 . 7}$ & $\mathbf{8 . 2}$ & $\mathbf{9 . 2}$ & $\mathbf{8 . 3}$ \\
\cline { 2 - 8 } & Male & 5.4 & 4.6 & 5.7 & 5.4 & 4.7 & 4.7 \\
\cline { 2 - 8 } & Female & 13.2 & 10.8 & 11.8 & 11.1 & 13.5 & 11.9 \\
\hline
\end{tabular}

Source: Department of Census and Statistics of Sri Lanka 
Table 10 on Sri Lanka's position in Social and Economic Development by Country Ranking shows her attractiveness for businesses undertakings local and foreign investors. Sri Lanka is far ahead in the following indices than other South Asian countries. Therefore, the country has a competitive edge for promoting businesses and attracting foreign investors to the country with the picture revealed by Table 10 .

Table 10: Sri Lanka's Position in Social and Economic Development by Country Ranking

\begin{tabular}{|l|l|l|l|l|l|l|}
\hline \multirow{2}{*}{ No. } & \multirow{2}{*}{$\begin{array}{c}\text { No. of } \\
\text { Countries }\end{array}$} & \multicolumn{5}{c|}{ Sri Lanka's Ranking } \\
\cline { 5 - 7 } & & & $\mathbf{2 0 1 0}$ & $\mathbf{2 0 1 2}$ & $\mathbf{2 0 1 4}$ & $\mathbf{2 0 1 5}$ \\
\hline 01 & Global Innovation Index & 142 & 79 & 94 & 105 & 85 \\
\hline 02 & Logistic Performance Index & 160 & $137(2007)$ & 81 & 89 & 113 \\
\hline 03 & Doing Business Index & 169 & 105 & 81 & 99 & $107(2015 / 17)$ \\
\hline 04 & $\begin{array}{l}\text { Global Competitiveness } \\
\text { Index }\end{array}$ & 148 & 62 & 69 & 73 & $68(2015 / 16)$ \\
\hline 05 & Basic Requirements Index & 148 & 73 & 72 & 75 & 78 \\
\hline 06 & $\begin{array}{l}\text { Human Development Index } \\
\text { (Value) }\end{array}$ & 186 & 0.705 & 0.7015 & $\begin{array}{l}0.750 \\
(2013)\end{array}$ & 0.757 \\
\hline 07 & Economic Freedom Index & 185 & 119 & 96 & $101(2015)$ & $93(2015 / 16)$ \\
\hline 08 & Global Peace Index & 162 & 133 & 103 & 105 & 114 \\
\hline 09 & Prosperity Index & 142 & 59 & 58 & 62 & 61 \\
\hline 10 & Prosperity Index (Value) & - & 58.2 & 66.8 & - & - \\
\hline 11 & Happiness Index & 157 & - & - & 133 & 117 \\
\hline 12 & Corruption Perception Index & 167 & - & - & 133 & 117 \\
\hline 13 & ICT Development Index & 155 & 105 & $105(2011)$ & $116(2013)$ & 115 \\
\hline
\end{tabular}

Source: Ministry of Finance - The Treasury of Sri Lanka (Accessed Date March 20, 2018http://www.treasury.gov.lk/country-ranking)

\section{Sri Lankan Economy In The Future}

It is evident that the Sri Lankan economy is moving forward amidst many internal and external pressures towards the achievement of her development goals for a long time and recently she has become a middle income country. There will be an extension to the Southern Expressway from Matara to Kataragama in the future and it will help the country to achieve her set developmental goals. The proposed Central Expressway is also a new addition to Sri Lanka and it will also help the country to achieve her development goals by making a fitting transportation system for the country and for goods and services to move around the country effortlessly. Therefore, in the future the highway systems and the convenient transportation system in Sri Lanka will definitely play a crucial role in her development process.

Sri Lanka has a high level of computer literacy and the present Government is also in the process of developing information communication technology in the country to a higher level. Sri Lanka is 116 out of 176 countries coming under this index. This is a better place compared to other South Asian countries such as Pakistan, Bangladesh, India, Bhutan, Nepal and Afghanistan. Sri Lanka is below only the Maldives in the ICT index in South Asia. Therefore, Sri Lankan's development and achievement of her development goals is solely dependent on the ICT development in the country and thereby aligning her industries to global standards through it.

Telecommunications is also a part and parcel of the day today life of the people today. Therefore, in the future the necessity for it will increase. Future development of the country as well as businesses will depend upon the successful usage of telecommunication in achieving the set goals. The Sri Lankan economy in the future will be highly affected by human rights, equal rights, ethics and environmental protection laws and regulations. Therefore, attitudes, values and inner happiness will have higher importance along with the quality of life merging with economic prosperity in Sri Lanka in the future. However, in the future there will be more unemployment and unrest amongst the youth. Therefore, the country must look to new ways and means to create new jobs for youth or any other opportunities with which occupy themselves and earn money for their living. Creating businesses and developing an entrepreneurial culture will be a solution as well as imperative. In the future, there will not be many employees in organizations since technological advancements and digitization are happening all over the world affecting businesses and development of other countries as well. The competitive and achievement oriented new generation needs new ways to develop themselves and achieve the pinnacle of their success. They look at their personal growth to a larger extent. Therefore, new economic goals need to be set along with the strategies to achieve them to support the new generation to attain their goals. Otherwise, the country may face the internal difficulties that she faced in 1971, 1989 and for 30 years. 
Hence, how can the mentality of the new generation are used for the development of the country? Isn't this a "paradox" with the way the country and the world are moving forward?

\section{Different Generations And Impact Of Their Life Styleson The Development Of The Country}

There are different generations living in this world and each individual in included to one of them. In fact, it is important for us to know the values and the characteristics of each generation in the endeavor to develop an entrepreneurial culture in Sri Lankan since such personalities may surely affect the setting of development goals in the country and developing businesses to support the modern world. There are five types of generations which canidentified in the literature viz Baby Boomers Generation, Generation X, Generation Y, Generation Z along with their characteristics.

- iGen, aka Generation Z born, 1996 and after- have a liking for stress, creativity, motivation

- Millennials, aka Generation Y born, 1977 - 1995-risk taking, have emotional stability, intellectual curiosity

- Generation X ,born 1965 - 1976- have competitiveness, social adaptability, collaboration

- The Baby Boomers generation, born 1946 - 1964-idealistic, democraticness, have social confidence

- Traditionalists, born 1945 and before- have flexibility, empathy

Therfore, it is important for the stategists to look into these genrations and their characterisitcs along with the economic and social conditions in the country when developing an entrpernuail culture.

\section{Sri Lankan Industry Structure}

Sri Lanka started her industrialization with the introduction of many policies after independence. The transformation made to the Sri Lankan economy in 1977 to alignher with world trends accelerated the industrialization of the country more than ever before. During the internal conflict for 30 years and the 1989 insurrection; everything was stuck in the country including industrialization. However, ending of the internal conflict paved the way for the country to look forward at a different angle by building new ports, air ports, infrastructure and highways. In Sri Lanka, the majority of the businesses are of sole proprietorships and partnerships. However, other forms of businesses consist of $30.3 \%$ of the total establishments in the country and they employ about $68.5 \%$ of the population. Table 11: No. of Establishments and Persons Engaged by Legal Organizations 2014 shows this information clearly.

Table 11: No. of Establishments and Persons Engaged by Legal Organizations 2014

\begin{tabular}{|l|l|l|l|l|}
\hline \multirow{2}{*}{ Legal Organization } & \multicolumn{2}{c|}{ Establishments } & \multicolumn{2}{c|}{ Persons Engaged } \\
\cline { 2 - 5 } & \multicolumn{1}{c|}{ Number } & \multicolumn{1}{c|}{ \% } & \multicolumn{1}{c|}{ Number } & \multicolumn{1}{c|}{} \\
\hline Sole Ownership & 12,670 & 62.3 & 297,609 & 26.5 \\
\hline Partnerships & 1,494 & 7.4 & 56,050 & 5.0 \\
\hline Others & 6,162 & 30.3 & 769,092 & 68.0 \\
\hline Total & 20,326 & 100.0 & $1,122,711$ & 100.0 \\
\hline
\end{tabular}

Source: Department of Census and Statitics, Aannual Survey of Industries, 2015, Final Report

In the industry sector, in 2014, the manufacturing sector had the highest percentage of establishments and employment as well. All data related to the industry sectors in 2014 are given in Table 12: No. of Establsihments, Persosns Engaged, Value Addition by Industry Sector-2014

Table 12: No. of Establsihments, Persosns Engaged, Value Addition by Industry Sector-2014

\begin{tabular}{|l|l|l|l|l|}
\hline \multirow{2}{*}{ Industry Sector } & \multicolumn{2}{c|}{ Establsihments } & \multicolumn{2}{c|}{ Persons Engaged } \\
\cline { 2 - 5 } & Number & \% & Number & \% \\
\hline Manufacuting & 16,835 & 82.8 & $1,063,086$ & 94.7 \\
\hline Mining and quarrying & 3,162 & 15.6 & 27,311 & 2.4 \\
\hline $\begin{array}{l}\text { Water supply, sewerage waste management and } \\
\text { remediation activities }\end{array}$ & 196 & 1.0 & 12,134 & 1.1 \\
\hline $\begin{array}{l}\text { Electricity, gas, steam and air conditioning } \\
\text { supply }\end{array}$ & 133 & 0.7 & 20,180 & 1.8 \\
\hline Total & $\mathbf{2 0 , 3 2 6}$ & $\mathbf{1 0 0 . 0}$ & $\mathbf{1 , 1 2 2 , 7 1 1}$ & $\mathbf{1 0 0 . 0}$ \\
\hline
\end{tabular}

Source: Department of Census and Statitics, Aannual Survey of Industries, 2015, Final Report

\section{Entrepreneurship- A Gist}

Different scholars have defined the term entrepreneur in different ways. According to such definitions an entrepreneur is a risk taker, an innovator, an opportunity seeker and an initiator. Many scholars argue that an entrepreneur takes 
calculated risks in business dealings and they are also internally locused (take the responsibility of the outcome for the work they do). Entrepreneurship is the process of taking risks, innovation, opportunity seeking and initiation.

Entrepreneurship is very important for a country to gain the desired level of economic growth whilst achieving the set goals. It also creates many employment opportunities for the masses which include all communities in the country. Entrepreneurship helps minorities and women in the country for receiving career alternatives which may help them to reduce some issues in the country and empower such communities in the country. Entrepreneurship also helps to foster creativity and innovation among people generating an indispensible talent to a country to achieve her set developmental goals.

Entrepreneurship also helps individuals in a country to gain control over their own destiny, to reach their full potential, to benefit financially, to contribute to society and be recognized for their effort.

At this point the issue is what is the importance of entrepreneurship to Sri Lanka? In fact, entrepreneurship is the backbone, life blood and vital spark of any country for her to achieve the desired level of development. Sri Lanka as a country had given priority to private entrepreneurship in 1977 as per the discussion in the previous sections, to achieve the development of the country. In the previous discussions it was highlighted that there is unemployment in the country in the urban and rural areas as well as among men and women separately. It is very important for the country to focus on this to minimize the unemployment to reduce the unrest among the communities as well as among the youth which may again give rise to chaos like the 30 year internal conflict in the country and the 1971, 1989insurrections. Sri Lanka must align herself with world trends and entrepreneurship will be a solution to it as well. As per the discussions above there are different generations in the country along with their own characteristics and expectations. Such expectations could be achieved and matched only by promoting entrepreneurship in the country.

Culture is that complex whole which includes knowledge, beliefs, art, law, morals, customs, and any capabilities and habits acquired by a person as a member of society. In simple terms culture is the natural behavior of a person or a group of people. Their behavior is an effortless and natural mechanism.

Sri Lanka needs to develop national systems for everything before developing a culture. National system is the prerequisite for the development of attitude towards the development of a culture. Therefore, it is better to identify the essential elements of developing entrepreneurship in Sri Lanka such as creativity and innovation by taking the initial experiences of other countries' prerequisite to their development. At the same time, fastly developing counties like China, India, Indonesia and Vietnamare also highly concentrating on creativity and innovation as core competencies of their development. Hence, should Sri Lanka try to develop a national innovation system to develop entrepreneurship through which to achieve the set developmental goals?

\section{Core Competancies For Entreprnurship}

As per the discussion in the previous section creativity and innovation are the life blood of a country for gaining a higher level of development. Developing a national innovation system based on them will be the starting point for developing a country through entrepreneurship. As per Figure 01: Greiner's Five-Stage Life Cycle, it is evident that an organization needs creativity and innovation at the introductory phase of its operation. This experience and the process could be replicated in a country like Sri Lanka in achieving her development goals to crown as a developed country. Therefore, this is the time for Sri Lanka to start thinking about a national innovation system,applying new ways of production processes, technology, thinking, organizations and marketing strategies. There are many misperceptions about creativity and innovation.

According to Levitt (1963) that creativity is thinking new things and innovation is doing new things. Creativity could be individual, organizational, sectorial, industry level and country level. However, for creativity two types of thinking must be there such as convergent and divergent. Innovation is the commercialization of the new idea whereas invention is the development of a prototype based on the new idea. Therefore, inventionplaces itself between creativity and innovation. Figure 02 shows thisProcess of Entrepreneurship.

There is a misperception among many that creativity cannot be taught. The modern view on this is that it can be taught and many training programs are going on all over the world with the expectation of developing entrepreneursin countries through creativity and innovation. 
Figure 01: Greiner's Five-Stage Life Cycle

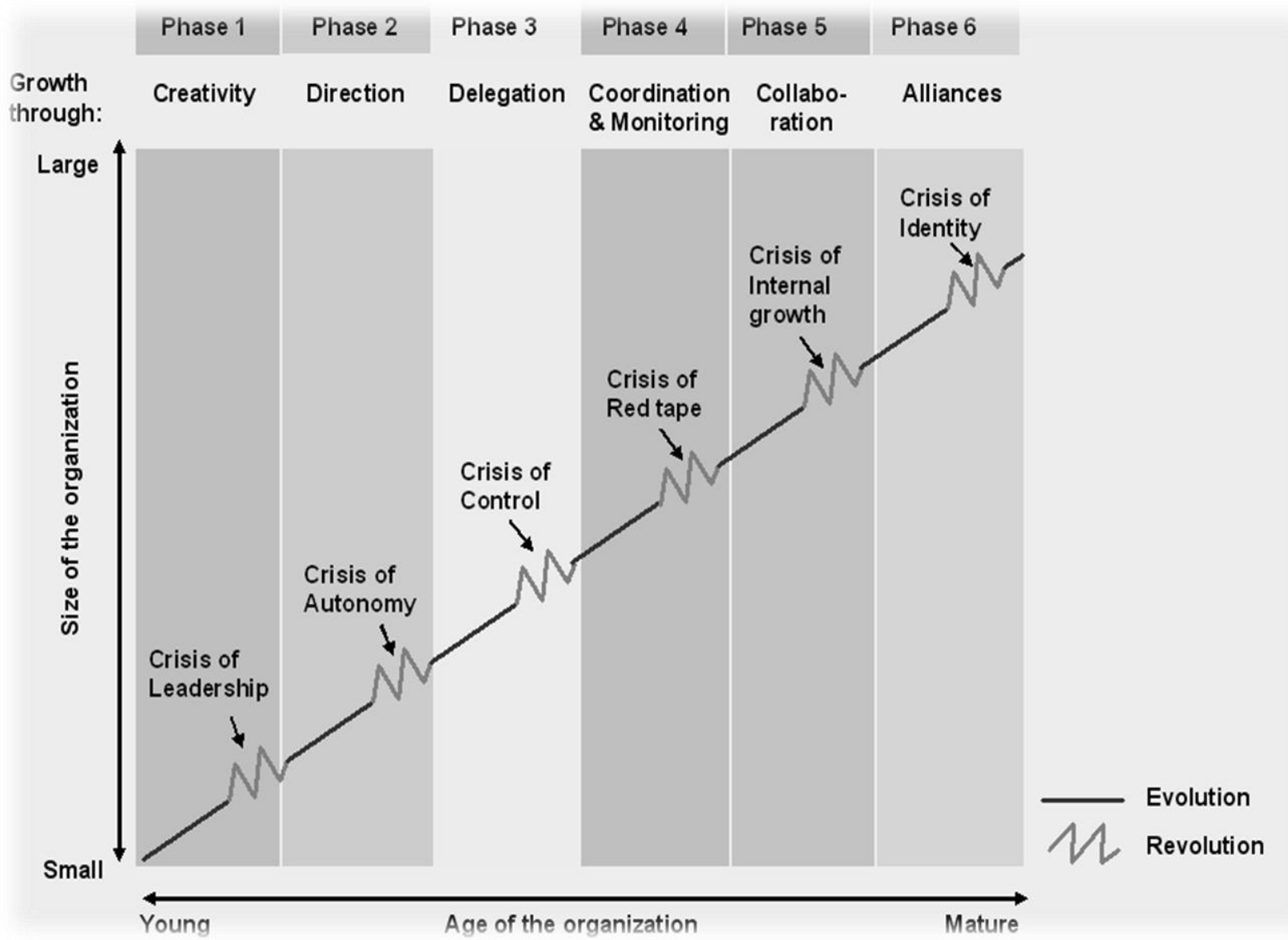

Source: Greiner Larry E., Evolution and Revolution as Organizations Grow. Harvard Business Review, pp 55-67, July/August 1998

Figure 02: Process of Entrepreneurship

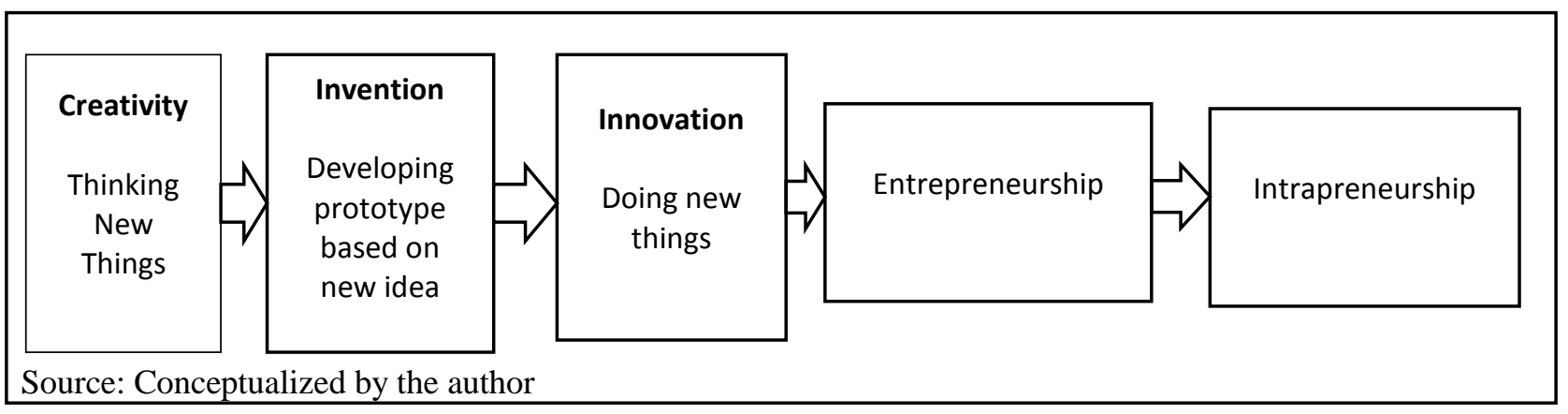

\section{What Is An Entrepreneurial Culture?}

An entrepreneurial culture is an environment where someone is motivated to create, innovate and take risks. In a business an entrepreneurial culture means that employees are encouraged to brainstorm new ideas or products. Entrepreneurial culture occurs when individuals of a country are empowered to create and manage their own businesses and when entrepreneurship is being considered as the vision of many individuals in organizations. The most entrepreneurial countries in G20 are shown in Table 13: The most entrepreneurial countries in the G20. 
Table 13: The Most Entrepreneurial Countries in the G20

\begin{tabular}{|l|l|c|}
\hline \multicolumn{1}{|c|}{ No. } & \multicolumn{1}{|c|}{ Country } & Rank \\
\hline 1 & 1.1 .1 US & 9.67 \\
\hline 2 & 1.1 .2 Germany & 8.65 \\
\hline 3 & 1.1 .3 Japan & 7.97 \\
\hline 4 & 1.1 .4 United Kingdom & 7.96 \\
\hline 5 & 1.1 .5 Canada & 7.80 \\
\hline 6 & 1.1 .6 Australia & 7.33 \\
\hline 7 & 1.1 .7 Saudi Arabia & 6.56 \\
\hline 8 & 1.1 .8 EU & 6.46 \\
\hline 9 & 1.1 .9 South Korea & 6.45 \\
\hline 10 & 1.1 .10 France & 6.10 \\
\hline 11 & 1.1 .11 South Africa & 4.61 \\
\hline 12 & 1.1 .12 Brazil & 4.84 \\
\hline 13 & 1.1 .13 Turkey & 4.45 \\
\hline 14 & 1.1 .14 Indonesia & 4.15 \\
\hline 15 & 1.1 .15 Mexico & 3.77 \\
\hline 16 & 1.1 .16 China & 3.68 \\
\hline 17 & 1.1 .17 Argentina & 2.59 \\
\hline 18 & 1.1 .18 Italy & 2.51 \\
\hline 19 & 1.1 .19 India & 2.46 \\
\hline 20 & 1.1 .20 Russia & 1.99 \\
\hline
\end{tabular}

Source: Business Insider UK, http://uk.businessinsider.com/ey-ranking-of-g20-countries-by-entrepreneurialculture-2016-9/\#20-russia--199-1 (Accessed Date: March 22, 2018)

Table 14: Best Country to be an Entrepreneur shows the countries which are more conducive to businesses by taken into consideration some criteria such as access to funding, entrepreneurship culture, tax and regulation, education and training and coordinated support. According to Table 13 above and the table 14 below; United State is the best country to be an entrepreneur and also it has the highest level of entrepreneurial culture as well. Therefore, Sri Lanka can look at such countries and use their experiences in the endeavor to develop entrepreneurship, a national innovation system and entrepreneurial culture to achieve the set developmental goals of the country. 
Table 14: Best Country to be an Entrepreneur

\begin{tabular}{|c|c|c|c|c|c|c|c|c|c|c|}
\hline 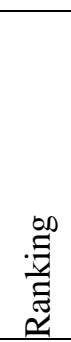 & 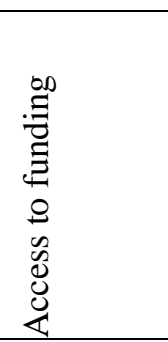 & $\begin{array}{l}0 \\
\ddot{0} \\
\ddot{n}\end{array}$ & 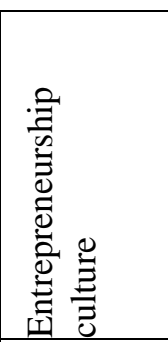 & $\begin{array}{l}0 \\
\ddot{0} \\
\ddot{n}\end{array}$ & 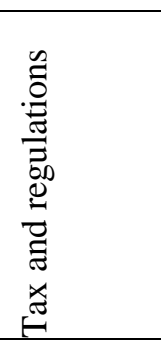 & $\begin{array}{l}0 \\
\ddot{0} \\
\ddot{n}\end{array}$ & 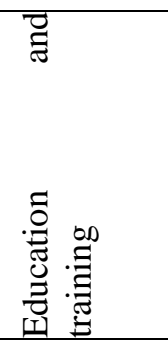 & $\begin{array}{l}0 \\
\ddot{0} \\
\ddot{n}\end{array}$ & 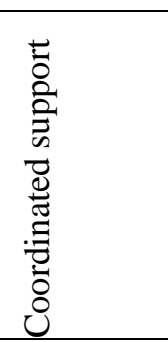 & $\begin{array}{l}0 \\
0 \\
0 \\
\end{array}$ \\
\hline 1 & US & 7.12 & $\overline{\mathrm{US}}$ & 7.67 & $\begin{array}{l}\text { Saudi } \\
\text { Arabia }\end{array}$ & 6.40 & France & 6.58 & Russia & 6.23 \\
\hline 2 & UK & 6.86 & $\begin{array}{l}\text { South } \\
\text { Korea }\end{array}$ & 7.53 & Canada & 6.34 & Australia & 6.53 & Mexico & 5.89 \\
\hline 3 & China & 7.75 & Canada & 7.45 & $\begin{array}{l}\text { South } \\
\text { Korea }\end{array}$ & 6.34 & US & 6.50 & Brazil & 5.87 \\
\hline 4 & Canada & 6.62 & Japan & 7.28 & UK & 6.19 & $\begin{array}{l}\text { South } \\
\text { Korea }\end{array}$ & 6.40 & Indonesia & 5.84 \\
\hline 5 & Australia & 6.68 & Australia & 7.18 & $\begin{array}{l}\text { South } \\
\text { Africa }\end{array}$ & 6.10 & $\mathrm{EU}$ & 6.25 & India & 5.76 \\
\hline 6 & $\begin{array}{l}\text { South } \\
\text { Africa }\end{array}$ & 5.95 & UK & 7.00 & Japan & 6.07 & UK & 5.98 & China & 5.75 \\
\hline 7 & Japan & 5.81 & Germany & 6.88 & Germany & 5.84 & Germany & 5.89 & Turkey & 5.66 \\
\hline 8 & $\begin{array}{l}\text { South } \\
\text { Korea }\end{array}$ & 5.75 & EU & 6.07 & Australia & 5.75 & Argentina & 5.85 & $\begin{array}{l}\text { South } \\
\text { Africa }\end{array}$ & 5.65 \\
\hline 9 & Brazil & 5.67 & France & 5.68 & Russia & 5.65 & Canada & 5.81 & Argentina & 5.64 \\
\hline 10 & Indonesia & 5.53 & Russia & 5.05 & EU & 5.48 & Brazil & 5.78 & Germany & 5.53 \\
\hline 11 & India & 5.48 & India & 4.95 & Turkey & 5.45 & $\begin{array}{l}\text { South } \\
\text { Africa }\end{array}$ & 5.67 & France & 5.41 \\
\hline 12 & EU & 5.41 & Brazil & 4.88 & Indonesia & 5.38 & $\begin{array}{l}\text { Saudi } \\
\text { Arabia }\end{array}$ & 5.66 & $\begin{array}{l}\text { Saudi } \\
\text { Arabia }\end{array}$ & 5.39 \\
\hline 13 & $\begin{array}{l}\text { Saudi } \\
\text { Arabia }\end{array}$ & 5.25 & Italy & 4.67 & US & 5.33 & Italy & 5.47 & EU & 5.37 \\
\hline 14 & Germany & 5.23 & $\begin{array}{l}\text { South } \\
\text { Africa }\end{array}$ & 4.33 & Mexico & 5.21 & Russia & 5.46 & $\begin{array}{l}\text { South } \\
\text { Korea }\end{array}$ & 5.36 \\
\hline 15 & Russia & 5.04 & Turkey & 4.30 & France & 5.12 & Mexico & 5.32 & Australia & 5.31 \\
\hline 16 & France & 4.74 & Argentina & 4.06 & China & 5.07 & Japan & 4.72 & Canada & 5.29 \\
\hline 17 & Turkey & 4.57 & Mexico & 3.96 & Brazil & 4.83 & Turkey & 4.39 & UK & 5.19 \\
\hline 18 & Mexico & 4.42 & China & 3.88 & Italy & 4.76 & China & 4.35 & Japan & 5.04 \\
\hline 19 & Italy & 4.03 & Indonesia & 3.80 & India & 4.39 & Indonesia & 3.88 & Italy & 4.97 \\
\hline 20 & Argentina & 3.27 & $\begin{array}{l}\text { Saudi } \\
\text { Arabia }\end{array}$ & 3.38 & Argentina & 4.31 & India & 3.49 & US & 4.84 \\
\hline
\end{tabular}

Source: Business Insider UK, http://www.businessinsider.com/best-country-to-be-an-entrepreneur-2013-8 ( Accessed Date: March 22, 2018)

When it comes to Sri Lanka ease of doing business can be seen by taking some criteria into consideration as Table 15: Ease of doing business in Sri Lanka 2010. Table 15 has compared nine factors with Singapore as a developed country and Chad as an under developed country. According to it, certain indicators are better in Sri Lanka for starting a business. 
Table 15: Ease of Doing a Business in Sri Lanka

\begin{tabular}{|l|c|c|c|}
\hline \multicolumn{1}{|c|}{ Criteria } & Singapore & Sri Lanka & Chad \\
\hline $\begin{array}{l}\text { Easy of Doing Business } \\
\text { (Rank) }\end{array}$ & 1 & 102 & 138 \\
\hline Starting a business & 4 & 34 & 182 \\
\hline $\begin{array}{l}\text { Dealing with } \\
\text { construction permits }\end{array}$ & 2 & 169 & 101 \\
\hline Registering property & 6 & 72 & 152 \\
\hline Protecting investors & 2 & 74 & 154 \\
\hline Paying taxes & 4 & 166 & 179 \\
\hline Trading across boarders & 1 & 72 & 164 \\
\hline Enforcing contracts & 13 & 137 & 183 \\
\hline Closing a business & 2 & 43 & \\
\hline
\end{tabular}

Source: Central Bank of Sri Lanka ( 2010)

- Chile- About $11 \%$ of its population chooses entrepreneurship.

- Botswana- $11.1 \%$ of the population are entrepreneurs

- Jamaica- $11.9 \%$ are self-employed, and many are street vendors.

- Angola-12.4\% of the population work for themselves.

- Vietnam-about $13.3 \%$ of the population is self-employed.

- Cameroon-13.7\% of the country is self-employed.

- Brazil-13.8\% is entrepreneurs and is predominantly single-person vendors.

- Thailand- $16.7 \%$ of the country work for themselves

- Uganda-a massive $28.1 \%$ of the population are entrepreneurs

This rate is near to $10 \%$ in Sri Lanka with all the number of establishments taken into consideration. It is a good percentage when compared to many countries in the world. Therefore, it is the responsibility of all Governments to increase this number and help the youth and the prospective entrepreneurs to become entrepreneurs in the country to support her development.

\section{What Is The Necessity of An Entrepreneurial Culture For Sri Lanka?}

Sri Lankan opened up her economy in 1977 to align herself with global trends and achieve a higher level of economic development like Singapore. However, due to the internal conflict of thirty years and the political disturbances of 1971 and 1989 severely affected the achievement of the level of development expected to be achieved by the new structural changes made. After the successful conclusion of the internal conflict, 2010 paved the way for Sri to commence new ways and means to achieve the level of development overlooked during the last two decades. Therefore, the then Government made use of them and was able to take Sri Lanka to the level of a middle income country from the status of Less Developed Country. Hence, the present challenge of Sri Lanka is to maintain this level as well as to go higher and achieve a higher level of development to crown her as the first developed country in South Asia. On the other hand, Sri Lanka has set developmental goals and infrastructure has been developing to support it. However, on the other hand she needs a set of strategies to achieve them in a novel way. Developing an entrepreneurial culture through creativity and innovation will be the strategy which gives competitive advantage in achieving the development of the Country. South Asian countries have not developed entrepreneurial cultures yet. They have a long way to go to achieve it. Therefore, Sri Lanka can make use of this gap and utilize it for the benefit of the country to achieve her development. Once the entrepreneurial culture is developed, it is easy for prospective businessmen and the investors to start and run businesses in Sri Lanka as it will be an attractive incentive for them. Hence, Sri Lanka must develop an entrepreneurial culture which is part and parcel of this life of the people in the country. At the same time, to empower women, minorities and underprivileged groups of the country, it is a burning necessity to create an entrepreneurial culture to face issues related to youth unrest in the country as the ones she faced in 1971 and 1989.

\section{How Can We Develop An Entrepreneurial Culture In Sri Lanka Through Creativity And Innovation?}

Developing an entrepreneurial culture is not a nightmare or a fairy tale. It could be made a reality, if the country uses the proper strategies to make it a reality. At the beginning, it may be a difficult endeavor. However, once the country launches the canoe properly; she will be able to carry out and achieve the ultimate outcome: an entrepreneurial culture which will support the country to achieve development. These strategies can be identified at individual level, organizational level, country level and global level. 


\subsection{Individual Level Strategies}

Individuals of the country can be trained to be entrepreneurs. In such training, mainly their skills and mind set need to be fine-tuned to be entrepreneurs in a context like Sri Lanka. Institutions which support the Small and Medium Enterprise Sector could be used in this endeavor. Industrial Development Board, Export Development Board, Industrial Technology Institute, National Engineering Research and Development Centre of Sri Lanka, National Design Centre, Banks, Technical Colleges, Universities, Chambers etc. can help in this endeavor. In Sri Lanka, many don't want to become entrepreneurs, even if someone wants to become entrepreneurs, one wants to start a service business too. This is a peculiar nature in Sri Lankans when it comes to business startups. Therefore, a rectification is neededfor this manifestation. There must be awareness workshops in creating the interest to become entrepreneurs and the aforementioned institutions can play a pivotal role in this connection.Individuals in the country face many issues with regard to finance, insurance, infrastructure, market, legal and other related services to a business. Therefore, special courses can be developed online and face to face by the educational institutes to cater to this need. At the same time, career guidance for potential entrepreneurs can be done by banks, insurance and leasing companies, educational institutes and chambers. Individuals of the country can be equipped with the principles, techniques and methods of creativity and innovation along with training to help an individual to become creative and innovative. There are many such trainings happening in developed countries and Sri Lanka can get the experience of them in developing the individuals of the country to be creative and innovative.

\subsection{Organizational Level Strategies}

The Sri Lankan private sector needs to be aware that it is the "engine of growth". Therefore, the whole burden in developing country lieswith them. Hence, it must work in a productive manner to make more entrepreneurs and look after the sustainability and survival of the exiting entrepreneurs as well. As a solution to this, organizations in Sri Lanka must be aware that they are practicing Intrapreneurship (entrepreneurship with an organization) in their organizations. Therefore, they do what entrepreneurs do as a team. This understanding will create many avenues for the development of an entrepreneurial culture in Sri Lanka.Organizations in Sri Lanka must be provided with resources, right employees, training programs, proper management practices, skills for employees, challenging work and freedom for employees to work. With this initiative, Sri Lankan organizations will be able to contribute to make an entrepreneurial culture through creativity and innovation. Most Sri Lankan organizations have rigid principals, autocratic leadership styles, hieratical barriers and cultural barriers to develop and contribute to the development of the country.

Therefore, such barriers must be eliminated from organizations to help the country's development.

\subsection{Country Level Strategies}

Sri Lanka is a country which does not have national policies for many things. Policy changes can be seen from one Government to another based on power changes. Therefore, there is policy inertia in Sri Lanka in developing an entrepreneurial culture. This affects almost all the things the country does and her performance too. Hence, the all Governments must take a decision that the polices are the same for at least certain areas such as education, economy and foreign trade etc. This type of policy decision will definitely pave the way for the country to develop and carry forward an entrepreneurial culture which supports the development of the country. Government must take a decision to give support of all Government institutions which facilitate businesses to create an entrepreneurial culture. Specially, the Central Bank of Sri Lanka, Public Banks, Government Treasury, Industrial Development Board and Chambers and the Government can assist these endeavors. Entrepreneurship, creativity and innovation can be an integral part of the primary, secondary, tertiary and University education. The main focus of the education of the country must be to create entrepreneurs rather than making employees (intraprenures) for organizations. This focus will definitely help the county to create an achievement oriented nation which will lead to an entrepreneurial culture as well.

\subsection{International Level Strategies}

There are many foreign Universities, institutions and some countries which support to develop a country as an entrepreneurial nation. Therefore, Sri Lanka can make use of their knowledge rather than "reinventing the wheel" to support our development by creating an entrepreneurial culture. There are organizations which give donations and consultancies to develop an entrepreneurial culture in countries. Hence, Sri Lanka can get such benefits out of them. As per the Global Innovation Index, it is evident that countries like China, Indonesia, Vietnam and India etc. are coming up in the global development index. Sri Lanka also can scrutinize their strategies and experiences to attain her development goals too. This will help Sri Lanka to develop an entrepreneurial culture along with creativity and innovation. 


\section{A Developed Sri Lanka Through An Entrepreneurial Culture: A Way Forward}

As per the discussion in many sections, it is evident that Sri Lanka has moved from a less developed country to a middle income category. However, it is not satisfactory when compared to the number of years spent after opening up the economy in 1977; it is almost 40years. Therefore, it is evident that the private sector has not done their job as the "engine of growth" in achieving the set developmental goals. Presently, the issue is how to overcome this lack? The only solution that this paper suggests is creating an entrepreneurial culture through which to develop new businesses and create wealth for the country which will help in the achievement of the desired level of development. In fact, Sri Lanka has faced three main issues during the last four decades; one is the internal conflict for 30 years and the other is 1971 and 1989 insurrections. These two contacts have had a high negative impact on the development of the country. That's why Sri Lanka started her development after 2010 and she became a middle income country subsequently. Many new big projects came to the country and they have helped the business of country directly. However, Sri Lanka missed many opportunities after the regime change in 2015to achieve her development due to political and social instability in the country. Even though, Sri Lanka has missed many opportunities, still she has competitive advantage in achieving her developmental goals and achieving the desired level of development. Finally, the only solution to achieve the development goal is developing an entrepreneurial culture through which the country can energize the private sector and develop an achievement oriented nation. Universities, other educational institutions and organizations which support businesses in the country can support developing an entrepreneurial culture in the country and Government support with a national level policy on this will give sustainability to the entrepreneurial culture movement in the country. At the same time, the development of the entrepreneurial culture must be merging with creativity and innovation to gain the competitive advantage over the development strategies of other countries and other emerging countries like Sri Lanka. In a nutshell, Sri Lanka must develop national policies, national innovation system and through them an entrepreneurial culture. The creation of the entrepreneurial culture will empower women, minorities and underprivileged communities along with unemployed or underemployed youth. Therefore, the outcome of the entrepreneurial culture gives many benefits to the country, businesses and specially, certain communities.

\section{References}

Asian development outlook 2016 Asia's potential growth(2016), Asian Development Bank.

Bessant, J. and Tidd, J. (2007, 3rd edition): Innovation and entrepreneurship. John Wiley \& Sons.Chichester, West Sussex, UK.

Bessant, T.J. and Pavitt, K. (2005): Managing Innovation. Wiley Science. Central Bank of Sri Lanka, Annual report ( 2010).

Central Bank of Sri Lanka, Economic Research Department, Sri Lanka: Macroeconomic Developments in Charts First Quarter 2017. Central Bank of Sri Lanka, https://www.cbsl.gov.lk/

De Mel S. (December 2008) Economic Policy Shifts in Sri Lanka, Economic Review, pp 43-45.Department of Census and Statitics, Aannual Survey of Industries, Final Report (2015). Department of Census and Statitics, http://www.statistics.gov.lk/

Developing Sri Lanka's Private Sector and Its Investment Opportunities (August 1983). Volume 1.Foxbuisness, http://video.foxbusiness.com/v/4483323/?\#sp=show-clips (Accessed date April 01, 2018)

GaneshamoorthyM. (Economic Review: June/July2011), Sri Lankan Economy: A critical Analysis of the past and present, pp10-18.

Global entrepreneurship monitor, (2015), Finnish 2015 Report.

Global entrepreneurship monitor, (2017/18), Global report.

Greiner L. E. (July/August 1998). Evolution and Revolution as Organizations Grow. Harvard Business Review, pp 5567.

Gunatilaka R, Wan G., and Chatterjee S.( 2009) Poverty and Human Development in Sri Lanka, Asian Development Bank.

Herring R.J. (Feb. 21, 1987), Economic Liberalization Policies in Sri Lanka: International Pressures, Constraints and Supports, Economic and Political Weekly, Vol. 22, No. 8, pp. 325-333.

ICT Development Index 2017, http://www.itu.int/net4/ITU-D/idi/2017/( Accessed Date March 20, 2017)

Indraratna Y. (2016), State of the economy: as reflected in the central bank annual report 2016, Economic Research Department, Central bank on Sri Lanka.

Investment Policy Review Sri Lanka,(2004), United Nations Conference on Trade And Development, United Nations.

Levitt, T. (May/June 1963), Creativity is not Enough. Harvard Business Review.

Lianna Brinded, Buisness Insider UK, The 9 countries with the most entrepreneurship, 
http://uk.businessinsider.com/top-9-countries-with-the-largest-amount-of-entrepreneurs-2015-6?r=US, (Accessed Date March 22, 2018).

Hamilton L. (Editor), Mitchell L. (Editor), Mangan A. (Editor), (2014) Contemporary Issues in Management, Edward Elgar.

Ministry of Finance - The Treasury of Sri Lanka (Accessed Date March 20, 2018- http://www.treasury.gov.lk/countryranking). Ministry of Finance Sri Lanka (2016), Annual Report.

Timmons J. A. (2007, 8th revised edition)), New Venture Creation: Entrepreneurship for the 21st Century Organization.

Sri Lanka Development Policy Review, (December 8, 2004), Poverty Reduction and Economic Management Sector Unit South Asia Region, Document of the World Bank, Report No. 29396-LK.

Sri Lanka Socio - Economic Data 2016, (June 2016), Central Bank of Sri Lanka.

Weerakoon D. and White H. ( 1992) How open has the Sri Lankan economy become? Trends in trade and trade taxes: 1977-93, Institute of Policy Studies.

Wickremasinghe S.I. (Jul-Aug 2011) The Status Of SMEs in Sri Lanka And Promotion of their Innovation Output Through Networking of S\&T Institutions, Tech MoniTor, Special Feature: Institutional Networking for Enhancing Innovation, pp11-19.

World Economic Outlook (April 2016, IMF), Depramtent of Census and Statisitics, Central Bank of Sri Lanka. 